\title{
Evaluation of wound healing activity of the polyherbal and Euphorbia hirta formulations
}

\author{
Kuldeep Ganju ${ }^{1 *}$ and A. K. Pathak ${ }^{2}$ \\ ${ }^{1}$ Principal, SIPTec, Gandhinagar, Bhopal, India. \\ ${ }^{2}$ Department of Pharmacy, B.U., Bhopal, India.
}

Accepted 26 July, 2013

\begin{abstract}
Evaluation of wound healing activity of polyherbal and Euphorbia hirta formulations was done. The study aimed at preparing a polyherbal formulation containing equal proportions of ethanolic extract of Tridax procumbens, Euphorbia hirta, Eclipta alba, dried rhizome of Curcuma longa and gel of Aloe barbadensis. Excision wound, incision wound and granulaoma wound models were studied. In excision wound model it was observed that $100 \%$ wound healing was found on 12 th day of the experiment on application of $10 \%$ polyherbal ointment and $100 \%$ wound contraction was found on 16th day of application of $10 \%$ ointment of $E$. hirta. The results were statistically compared with control and found significant. Similarly, period of epithelilization, biochemical parameters and weight of granuloma tissues showed better results in the treated groups when compared with control in the studied wound models. Thus it is concluded that topical and oral formulations were found to contain significant wound healing activity.
\end{abstract}

Key words: Excision wound, incision wound, granuloma.

\section{INTRODUCTION}

More than $80 \%$ of the world's population still depends upon traditional medicines for various skin diseases (Babu et al., 2002). Herbal medicines in wound management involve disinfection, debridement and providing a moist environment to encourage the establishment of the suitable environment for natural healing process (Purna and Babu, 2000). Healing is the body response to injury in an attempt to restore normal structure and function. The process of healing involves two distinct processes: regeneration when healing takes place by proliferation of parenchymal cells and usually results in complete restoration of the original cells, and repair when that healing takes place by proliferation of connective tissue elements resulting in fibrosis and scarring (Harshmohan, 2002). Wound healing involves a complex series of interactions between different cell types, cytokine mediators, and the extracellular matrix. The phases of normal wound healing include hemostasis, inflammation, proliferation, and remodeling. Each phase of wound healing is distinct, although the wound healing process is continuous, with each phase overlapping the next. Open wounds are colonized by bacteria and systemic antibiotics are only indicated if invasive infections is present (Lorenz et al., 2003). The formulation which claims to possess wound healing activity shall be studied with the features like tensile strength of newly formed tissue, biochemical parameters like serum and tissue levels of hydroxyproline, lysyl oxidase, methionine, ascorbic acid etc. which contribute to the all round healing of wound. 


\section{MATERIAL AND METHODS}

\section{Plants used}

Gel of Aloe barbadensis, family Liliaceae containing glucomannan (Rastogi and Mehrotra, 1999), rhizomes of Curcuma longa family Zingiberaceae containing yellow matter curcumins (API, 1998), whole plant of Eclipta alba family Compositae containing coumestan derivatives, wedelolactones and demethylwedelolactone (Govindachari et al., 1956; Wagner et al., 1986), whole plant of Euphorbia hirta containing leucocyanidol, quercitol, camphol, quercitin and quercitol derivatives containing rhamnose and chlorophenolic acid (Rastogi and Mehrotra, 1999) and whole plant of Tridax procumbens containing $\beta$-amyrin, fucosterol and sitosterol, arachidic, behenic, lauric, linoeic, linolenic, myristic, palmitic and stearic acids (Rastogi and Mehrotra, 1999).

\section{Extraction}

Dried ethanolic extract of the dried rhizome of Curcuma longa and dried whole plants of $T$. procumbens, Eclipta alba, E. hirta was taken and gel of Aloe barabadensis was collected.

\section{Formulation of topical and oral formulations}

\section{Topical formulation (ointment)}

Two ointments were prepared by fusion method that is, one containing ethanolic extract of whole plant of Euphorbia hirta $(10 \%$ $\mathrm{w} / \mathrm{w})$, and other containing equal proportions (2 $\mathrm{g}$ each) of ethanolic extract of whole plant of $T$. procumbens, ethanolic extract of whole plant of $E$. alba, ethanolic extract of whole plant of $E$. hirta, ethanolic extract of dried rhizomes of Curcuma longa and gel of Aloe barbadensis $(10 \% \mathrm{w} / \mathrm{w})$ in hydrophilic ointment USP base.

\section{Oral formulation (suspension)}

Two suspensions were formulated that is, one containing ethanolic extract of whole plant of $E$. hirta $(10 \% \mathrm{w} / \mathrm{v})$ and other containing equal proportions ( $2.5 \mathrm{~g}$ each) of ethanolic extract of whole plant of $T$. procumbens, ethanolic extract of whole plant of $E$. alba, ethanolic extract of whole plant of $E$. hirta and ethanolic extract of dried rhizomes of $C$. longa to make $10 \% \mathrm{w} / \mathrm{v}$ of suspensions.

\section{Evaluation of E. hirta and polyherbal formulations for wound healing activity}

All the animal studies were performed in Department of pharmacy, Barkatullah university, Bhopal. The department is an Animal Ethical Committee approved institution. The approval was granted by meeting held on 26/12/2006 with ref. No. BUPH/AEC/7865. The department is also approved for animal experimentation (Letter No. 444/01/C/CPCSEA Dated July 2001).

\section{Excision wound model}

For the excision wound study, each group containing six animals were selected. A wound of about $1 \mathrm{~cm}^{2}$ area was made on the depilated dorsal thoracic region of rats. To make the wound, the rats were anaesthetized under light ether. The aseptic conditions were maintained and observed throughout the study. The wounded rats were individually caged and percentage wound closures were observed from 2nd post wounding day to 22nd day, alternately (Morton and Malone, 1972).

\section{Topical application}

\section{Group I (control)}

The hydrophilic ointment base was applied topically, once daily.

\section{Group II (Test 1)}

$10 \%$ ointment, in hydrophilic base, of $95 \%$ ethanolic extract of whole plant of Euphorbia hirta was topically applied, once daily.

\section{Group III (Test 2)}

$10 \%$ polyherbal formulation was topically applied, once daily.

\section{Oral administration}

\section{Group I (control)}

$2 \%$ tragacanth suspension was given orally, once daily, $200 \mathrm{mg} / \mathrm{kg}$ BW.

\section{Group II (test 1)}

$10 \% \mathrm{w} / \mathrm{v}$ suspension of $95 \%$ ethanolic extract of whole plant of $E$. hirta in $2 \%$ tragacanth was given orally, once daily, $200 \mathrm{mg} / \mathrm{kg} \mathrm{BW}$.

\section{Group III (test 2)}

$10 \% \mathrm{w} / \mathrm{v}$ suspension of polyherbal formulation in $2 \%$ tragacanth was given orally, once daily, $200 \mathrm{mg} / \mathrm{kg}$ BW. Parameter of percentage wound contraction and period of epithelialization were evaluated. Biochemical parameters like determination of hydroxylproline (Newman and Logman, 1950), hexosamine (Dische and Borenfreund, 1950) and protein content (Lowry et al., 1951) were also evaluated on 11th post wounding day. The percentage wound contraction was determined using the formula:

$\%$ wound contraction $=($ Healed area $/$ Total area $) \times 100$

Wound contraction was measured each day using graph paper planimetrically.

\section{Incision wound model}

Thirty six male albino rats of either sex weighing 150 to $200 \mathrm{~g}$ were taken. Paravertebral incisions of $3 \mathrm{~cm}$ were made on the depilated skin of the rats anaesthetized under light ether with the help of a surgical blade. The incisions were sutured using 4 to 0 silk thread with cutting edges. Sutures were removed on the 8th post wounding day and the tensile strength were determined on 11th post wounding day by continuous constant water flow technique of Lee (Lee, 1968) of the rats of each group. White blood cell (WBC) count was also done to evaluate the extent of protection (Ehrlich and Hunt, 1969). 
Table 1. Percentage wound contraction in excision wound model by topical application.

\begin{tabular}{cccc}
\hline Days & Control & Test 1 & Test 2 \\
\hline 2 & $19.23 \pm 0.94$ & $25.41 \pm 1.05^{\star}$ & $28.25 \pm 1.11^{*}$ \\
4 & $22.31 \pm 0.87$ & $42.83 \pm 0.90^{\star}$ & $47.15 \pm 0.92^{\star}$ \\
6 & $27.7 \pm 1.28$ & $73.61 \pm 0.89^{\star}$ & $75.72 \pm 0.96^{\star}$ \\
8 & $33.34 \pm 0.84$ & $81.26 \pm 0.99^{\star}$ & $92.36 \pm 1.07^{*}$ \\
10 & $35.62 \pm 0.96$ & $88.42 \pm 1.20^{*}$ & $97.42 \pm 0.95^{\star}$ \\
12 & $40.57 \pm 1.21$ & $92.33 \pm 0.94^{*}$ & $100 \pm 1.03^{*}$ \\
14 & $44.12 \pm 1.17$ & $96.14 \pm 1.13^{*}$ & - \\
16 & $49.68 \pm 1.16$ & $100 \pm 1.08^{*}$ & - \\
18 & $53.21 \pm 0.91$ & - & - \\
20 & $57.81 \pm 1.10$ & - & - \\
22 & $60.33 \pm 0.88$ & - & - \\
\hline
\end{tabular}

Each group contain six animals, Mean \pm SD. *Indicates significant activity at $\mathrm{p}<0.001$. "Indicates post wounding days.

\section{Topical application}

\section{Group I (control)}

The hydrophilic ointment base was applied topically, once daily.

\section{Group II (Test 1)}

$10 \%$ ointment, in hydrophilic base, of $95 \%$ ethanolic extract of whole plant of $E$. hirta was topically applied, once daily.

\section{Group III (Test 2)}

$10 \%$ polyherbal formulation was topically applied, once daily

\section{Oral administration}

\section{Group I (Control)}

$2 \%$ tragacanth suspension was given orally, once daily, $200 \mathrm{mg} / \mathrm{kg}$ BW.

\section{Group II (Test 1)}

$10 \% \mathrm{w} / \mathrm{v}$ suspension of $95 \%$ ethanolic extract of whole plant of Euphorbia hirta in $2 \%$ tragacanth was given orally, once daily, 200 $\mathrm{mg} / \mathrm{kg} \mathrm{BW}$.

\section{Group III (Test 2)}

$10 \% \mathrm{w} / \mathrm{v}$ suspension of polyherbal formulation in $2 \%$ tragacanth was given orally, once daily, $200 \mathrm{mg} / \mathrm{kg} \mathrm{BW}$. Measurement of tensile strength and total leucocytes count WBC (Shanbhag et al., 2005).

\section{Dead space wound model}

Thirty six albino rats of either sex were taken. Under light ether anesthesia, subcutaneous dead space wound was inflicted in the paravertebral lumbar region by making a pouch through a small nick in the skin. Sterile polypropylene tubes measuring $2.5 \mathrm{~cm}$ in length and $0.5 \mathrm{~cm}$ in diameter were introduced in the pouch to induce granuloma formation. Each animal received two polypropylene tubes in the groin region. The wounds were sutured and mopped with an alcoholic swab. The harvesting of the granuloma tissue from the surrounding tissue was carried out on the $11^{\text {th }}$ post wounding day. Then it was subjected to measurement of bearing strength of granuloma tissue and histopathological examination. The weight of wet and dry granulation tissue was measured along with the estimation of biochemical parameters like hydroxyproline, hexosamine and protein content (Turner, 1965).

\section{Topical application}

\section{Group I (control)}

The hydrophilic ointment base was applied topically, once daily.

\section{Group II (test 1)}

$10 \%$ ointment, in hydrophilic base, of $95 \%$ ethanolic extract of whole plant of $E$. hirta was topically applied, once daily.

\section{Group III (test 2)}

$10 \%$ polyherbal formulation was topically applied, once daily.

\section{Oral administration}

\section{Group I (control)}

$2 \%$ tragacanth suspension was given orally, once daily, $200 \mathrm{mg} / \mathrm{kg}$ BW.

\section{Group II (test 1)}

$10 \% \mathrm{w} / \mathrm{v}$ suspension of $95 \%$ ethanolic extract of whole plant of $E$. hirta in $2 \%$ tragacanth was given orally, once daily, $200 \mathrm{mg} / \mathrm{kg} \mathrm{BW}$.

\section{Group III (test 2)}

$10 \% \mathrm{w} / \mathrm{v}$ suspension of polyherbal formulation in $2 \%$ tragacanth was given orally, once daily, $200 \mathrm{mg} / \mathrm{kg} \mathrm{BW}$.

\section{DISCUSSION}

The wound healing activity was evaluated by excision wound model, incision wound model, dead space wound model, burn wound model and induced diabetes wound healing model. In excision wound model, it was observed that $100 \%$ wound healing was found on 12 th day of the experiment on application of $10 \%$ polyherbal ointment and $100 \%$ wound contraction was found on 16th day of application of $10 \%$ ointment of $E$. hirta. The results were statistically compared with control and found significant (Tables 1 and 2). On oral administration of the formulated 
Table 2. Percentage wound contraction in excision wound model by oral administration.

\begin{tabular}{cccc}
\hline Days $^{\#}$ & Control & Test 1 & Test 2 \\
\hline 2 & $16.20 \pm 0.81$ & $23.42 \pm 0.93^{*}$ & $38.11 \pm 1.26^{*}$ \\
4 & $20.31 \pm 1.15$ & $47.32 \pm 1.17^{*}$ & $49.66 \pm 0.99^{*}$ \\
6 & $30.61 \pm 0.54$ & $55.64 \pm 0.96^{*}$ & $58.15 \pm 0.93^{*}$ \\
8 & $35.57 \pm 0.97$ & $69.91 \pm 1.27^{*}$ & $66.62 \pm 1.36^{*}$ \\
10 & $37.17 \pm 0.56$ & $76.37 \pm 0.86^{*}$ & $79.41 \pm 1.26^{*}$ \\
12 & $41.88 \pm 0.87$ & $81.2 \pm 0.76^{*}$ & $85.0 \pm 1.42^{*}$ \\
14 & $46.20 \pm 0.41$ & $87.5 \pm 0.88^{*}$ & $100 \pm 0.93^{*}$ \\
16 & $49.42 \pm 0.98$ & $94.41 \pm 1.20^{*}$ & - \\
18 & $55.90 \pm 1.15$ & $100 \pm 1.31^{*}$ & - \\
20 & $59.50 \pm 0.87$ & - & - \\
22 & $62.76 \pm 0.84$ & - & - \\
\hline
\end{tabular}

Each group contain six animals, Mean $\pm S D$;

\#Indicates Post Wounding Days *Indicates significant activity at $P<0.001$.

Table 3. Period of epithelization (days) in excision wound model.

\begin{tabular}{lcc}
\hline \multirow{2}{*}{ Groups } & \multicolumn{2}{c}{ Period of epithelization (days) } \\
\cline { 2 - 3 } & Topical (ointment) & Oral (suspension) \\
\hline Control & $26.17 \pm 1.15$ & $28.45 \pm 1.21$ \\
Test 1 & $15.12 \pm 0.85$ & $17.20 \pm 1.22$ \\
Test 2 & $11.61 \pm 1.10$ & $13.12 \pm 1.34$ \\
\hline
\end{tabular}

Each group contain six animals, Mean \pm SD. ${ }^{*}$ Indicates significant activity at $P<0.001$.

Table 4. Biochemical Parameters of Excision wound model on Topical Application on $11^{\text {th }}$ Post Wounding Day.

\begin{tabular}{lccc}
\hline $\begin{array}{l}\text { Parameter } \\
\text { (mg/g tissue wt.) }\end{array}$ & Control & Test 1 & Test 2 \\
\hline Hydroxyproline & $19.1 \pm 1.3$ & $31.3 \pm 2.3^{*}$ & $74.1 \pm 2.5^{*}$ \\
Hexosamine & $3.3 \pm 0.4$ & $12.1 \pm 1.3^{*}$ & $24.3 \pm 2.0^{*}$ \\
Protein & $19.6 \pm 1.3$ & $35.0 \pm 1.8^{*}$ & $68.3 \pm 1.0^{*}$ \\
\hline
\end{tabular}

Values are expressed as Mean $\pm S D$ * indicates significant activity $\mathrm{P}<0.01$.

Table 5. Biochemical parameters of excision wound model on oral administration on 11th post wounding day.

\begin{tabular}{lccc}
\hline $\begin{array}{l}\text { Parameter } \\
\text { (mg/g tissue wt.) }\end{array}$ & Control & Test 1 & Test 2 \\
\hline Hydroxyproline & $16.8 \pm 2.1$ & $28.4 \pm 1.8^{*}$ & $59.5 \pm 2.2^{*}$ \\
Hexosamine & $5.1 \pm 0.2$ & $9.5 \pm 1.1^{*}$ & $20.2 \pm 0.23^{*}$ \\
Protein & $17.3 \pm 1.2$ & $31.3 \pm 1.0^{*}$ & $56.0 \pm 1.8^{*}$ \\
\hline
\end{tabular}

Values are expressed as Mean $\pm S D$; ${ }^{*}$ Indicates significant activity $\mathrm{P}<0.01$. suspensions it was found that $100 \%$ wound contraction on 14th day was shown by rats treated with polyherbal suspensions whereas complete wound contraction was found on 18th day in E. hirta treated group. The results were compared statistically with control and found satisfactory (Table 3 ). The period of Epithelization was also found to be significantly shorter for the treated groups as compared to control. However the results were more encouraging for the polyherbal ointment (Table 4). Estimation of biochemical parameters- hydroxyproline, hexosamine and protein content was done on the 11th post wounding day and it was found that the respective concentrations of the parameters increased in the treated groups, however the increase was most marked in the topically applied polyherbal formulation followed by polyherbal oral formulation. It was reported that besides collagen $\mathrm{C} 1 \mathrm{q}$ of the complement system contains considerable amount of collagen (Nagelschmidt and Struck, 1977). The increase in the biochemical parameters of the topical and oral E. hirta formulations was also found to be significant when compared to control (Tables 5 and 6). The period of epithelization was found to be least in the topical polyherbal formulation and that of the oral polyherbal was found to be better than $E$. hirta topical formulation.

In the incision wound model, the tensile strength of the new generated tissue was measured. Collagen, the major protein of the extracellular matrix, is the component that ultimately liberates free hydroxyproline and its peptides (Nayak and Pereira, 2006). The tensile strength of a wound is determined by the rate of collagen synthesis and more so, by the maturation process where there is a covalent binding of collagen fibrils through inter and intra molecular cross linking (Malviya and Jain, 2009). It was found that the tensile strength of new tissue was more in the treated groups with least significant signs of infection. The strength of the tissues was statistically significant in the polyherbal topical group followed by polyherbal oral group (Table 6).

In dead space wound model, it was found that the weight of wet and dry granuloma tissue formed was more in the case of treated groups when compared to control. The increase in the weight of the granuloma was most significant in the topically applied polyherbal formulation groups followed by orally administered polyherbal groups. Similarly, the rise in the biochemical parameters like those of hydroxyproline, hexosamine and protein content of the granuloma tissue was lot more in both topically and orally treated groups. However, the results were most encouraging and statistically significant in the topically treated polyherbal formulations, when compared with control (Table 7 and 8). Histopathological studies showed formation of scanty collagen tissue in the control group (Figures 1 and 2). The test groups treated with polyherbal topical formulations showed formation of dense collagen tissues with minimum presence of macrophages (Figure 2d) and formation of complete epidermis (Figure 2c). 
Table 6. Effect of formulations on tensile strength and WBC count in incision wound model.

\begin{tabular}{lcccc}
\hline \multirow{2}{*}{ Group } & \multicolumn{2}{c}{ Tensile strength $\mathbf{g})$} & \multicolumn{2}{c}{ WBC count $\left(\times \mathbf{1 0}^{\mathbf{3}} \mathbf{c e l l} / \mathbf{m m}^{\mathbf{3}}\right)$} \\
\cline { 2 - 5 } & Topical & Oral & 0th Day & 10th Day \\
\hline Control & $223 \pm 3.5$ & $215 \pm 3.3$ & $13.95 \pm 0.51$ & $30.52 \pm 1.15$ \\
Test 1 & $330 \pm 4.2^{*}$ & $302 \pm 3.3^{*}$ & $14.0 \pm 0.62^{*}$ & $13.98 \pm 1.10^{*}$ \\
Test 2 & $360 \pm 6.3^{*}$ & $347 \pm 4.1^{*}$ & $14.0 \pm 0.46^{*}$ & $13.97 \pm 1.12^{*}$ \\
\hline
\end{tabular}

Table 7. Physical and biochemical parameters by topical application in dead space wound model.

\begin{tabular}{lccc}
\hline Parameter & Control & Test 1 & Test 2 \\
\hline Wet granulation weight $(\mathrm{mg} / 100 \mathrm{~g})$ & $229 \pm 11.2$ & $380.41 \pm 13.2^{*}$ & $483.4 \pm 15.3^{*}$ \\
Dry granulation weight $(\mathrm{mg} / 100 \mathrm{~g})$ & $25.1 \pm 3.1$ & $77.0 \pm 1.4^{*}$ & $94.3 \pm 1.5^{*}$ \\
Protein $\left(\mathrm{mg} \mathrm{g}^{-1}\right)$ & $19.71 \pm 1.5$ & $34.1 \pm 2.1^{*}$ & $64.1 \pm 2.1^{*}$ \\
Hydroxyproline $\left(\mathrm{mg} \mathrm{g}^{-1}\right)$ & $16.93 \pm 1.2$ & $22.4 \pm 2.6^{*}$ & $30.9 \pm 2.1^{*}$ \\
Hexosamine $\left(\mathrm{mg} \mathrm{g}^{-1}\right)$ & $9.74 \pm 0.05$ & $16.4 \pm 1.9^{*}$ & $28.1 \pm 1.4^{*}$ \\
\hline
\end{tabular}

All values are expressed as mean \pm S.D. ${ }^{*} \mathrm{P}<0.01$ significant compared to control.

Table 8. Physical and biochemical parameters by oral administration in dead space wound model.

\begin{tabular}{lccc}
\hline Parameter & Control & Test 1 & Test 2 \\
\hline Wet granulation Weight $(\mathrm{mg} / 100 \mathrm{~g})$ & $220 \pm 10.4$ & $289.5 \pm 14.1^{*}$ & $415.2 \pm 10.3^{*}$ \\
Dry granulation weight $(\mathrm{mg} / 100 \mathrm{~g})$ & $31.3 \pm 1.6$ & $70.0 \pm 1.2^{*}$ & $89.1 \pm 2.3^{*}$ \\
Protein $\left(\mathrm{mg} \mathrm{g}^{-1}\right)$ & $21.5 \pm 1.4$ & $50.5 \pm 2.1^{*}$ & $62.1 \pm 1.5^{*}$ \\
Hydroxyproline $\left(\mathrm{mg} \mathrm{g}^{-1}\right)$ & $3.2 \pm 0.08$ & $5.12 \pm 1.5^{\star}$ & $24.96 \pm 1.3^{*}$ \\
Hexosamine $\left(\mathrm{mg} \mathrm{g}^{-1}\right)$ & $8.5 \pm 0.05$ & $14.8 \pm 1.2^{*}$ & $23.6 \pm 1.5^{*}$ \\
\hline
\end{tabular}

All values are expressed as mean $\pm S D$. ${ }^{*} P<0.01$ significant compared to control.

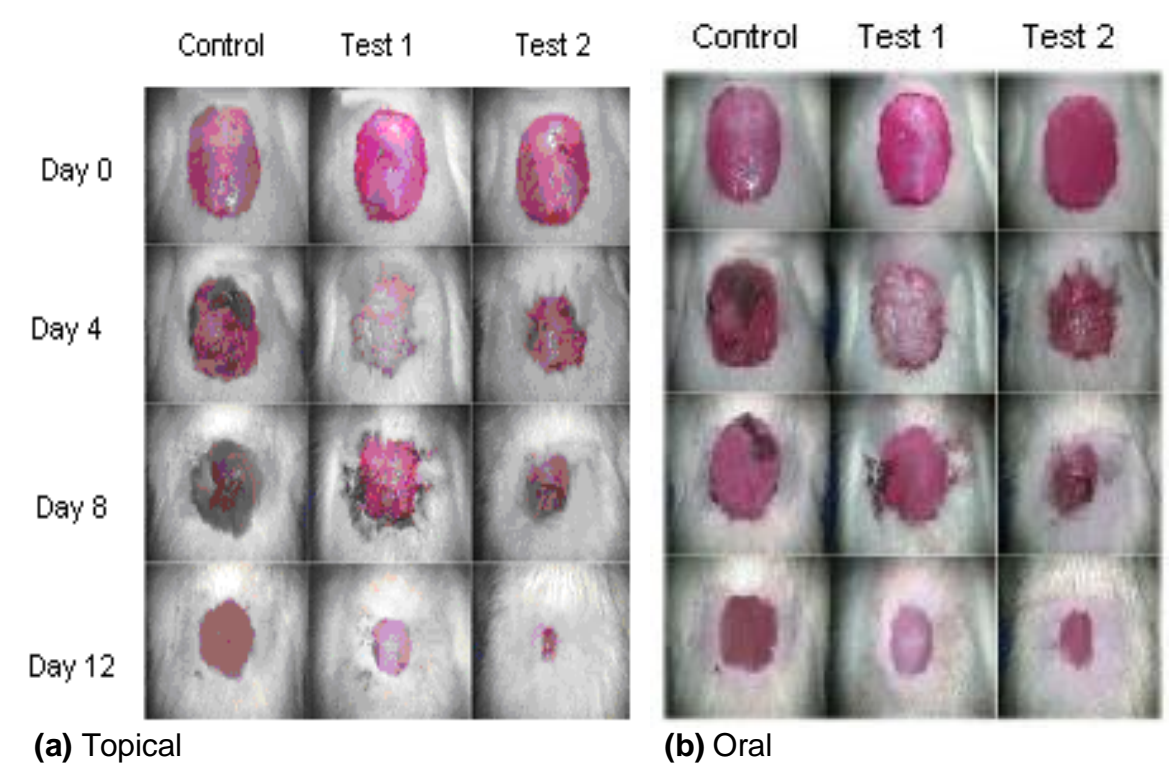

(a) Topical

(b) Oral

Figure 1. Wound contraction in excision wound model. 


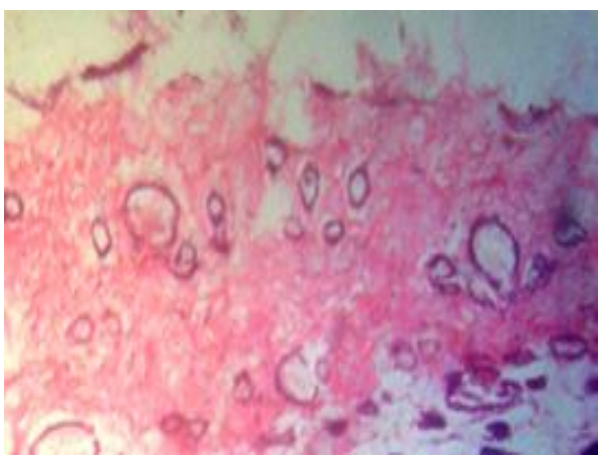

(a)

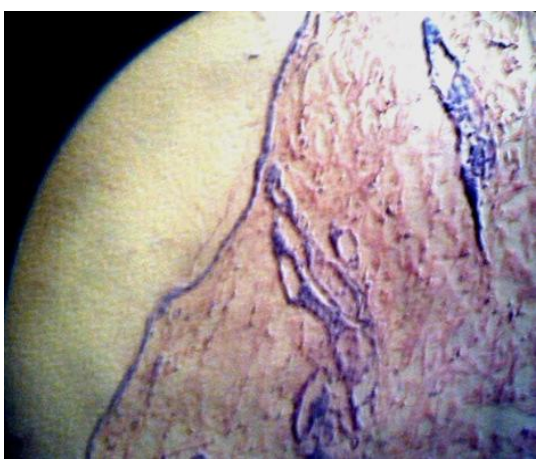

(c)

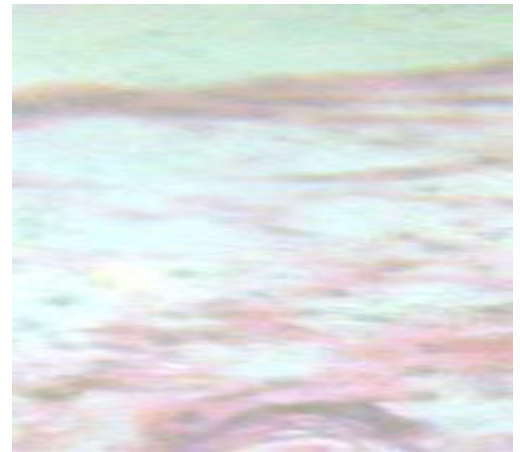

(b)

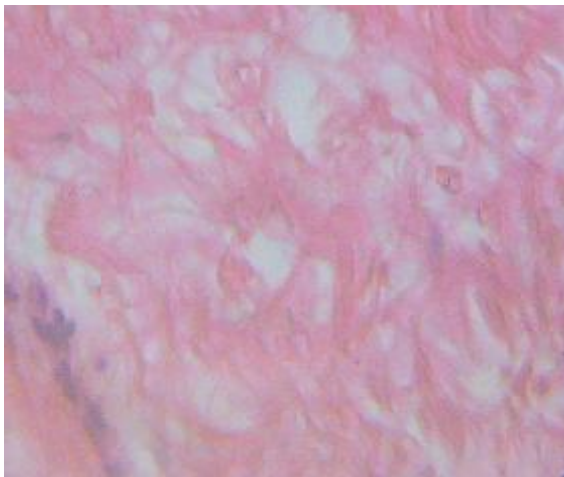

(d)

Figure 2. Histopathology of dead space wound model (a) control (oral), (b) control (topical), (c) Test 1 (topical), (d) Test 2 (topical).

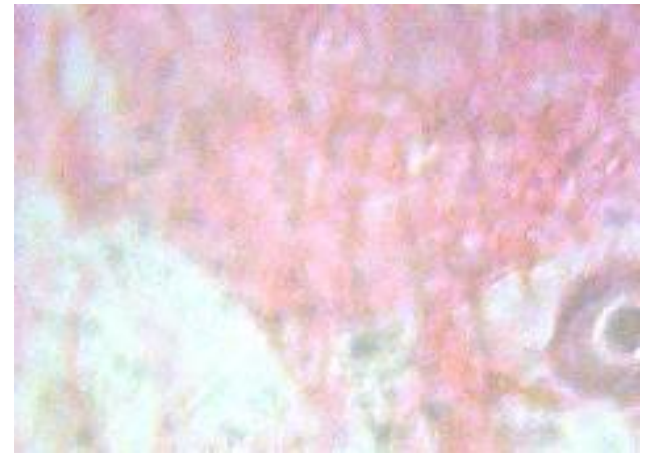

(a)

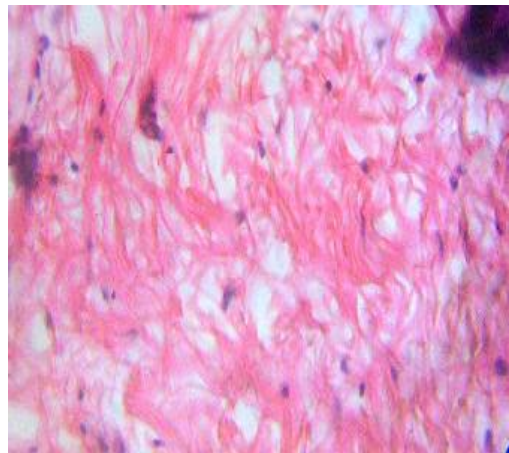

(b)

Figure 3. Complete epidermis (a) Test 1 (oral), Test 2 (oral).

The best groups treated with polyherbal oral formulations also showed formation of dense collagen tissues, but slightly less than topically treated groups by polyherbal formulations (Figure $3 b$ ). The test group treated with topical formulation of $E$. hirta showed formation of collagen tissues with presence of macrophages (Figure $2 \mathrm{c}$ ), whereas those treated with oral $E$. hirta formulations showed collagen tissues less than in the topically treated groups of E. hirta (Figure 3a).

The wound healing studies revealed that the polyherbal and $E$. hirta formulations possess significant activity but it may be concluded that the polyherbal topical formulations has got remarkable results in all types of wound healing protocols (Figures 4 and 5). The study has concluded to acclaim E. hirta as a prominent wound healer $(200 \mathrm{mg} / \mathrm{kg}$ BW).

\section{Conclusion}

The polyherbal formulations containing equal proportions 


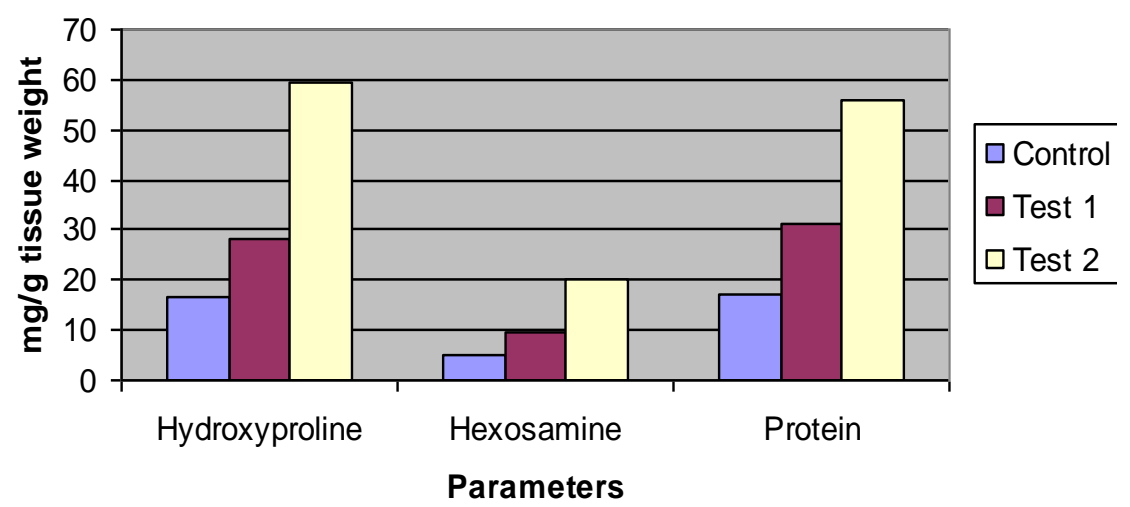

Figure 4. Biochemical parameters of excision wound model on oral administration

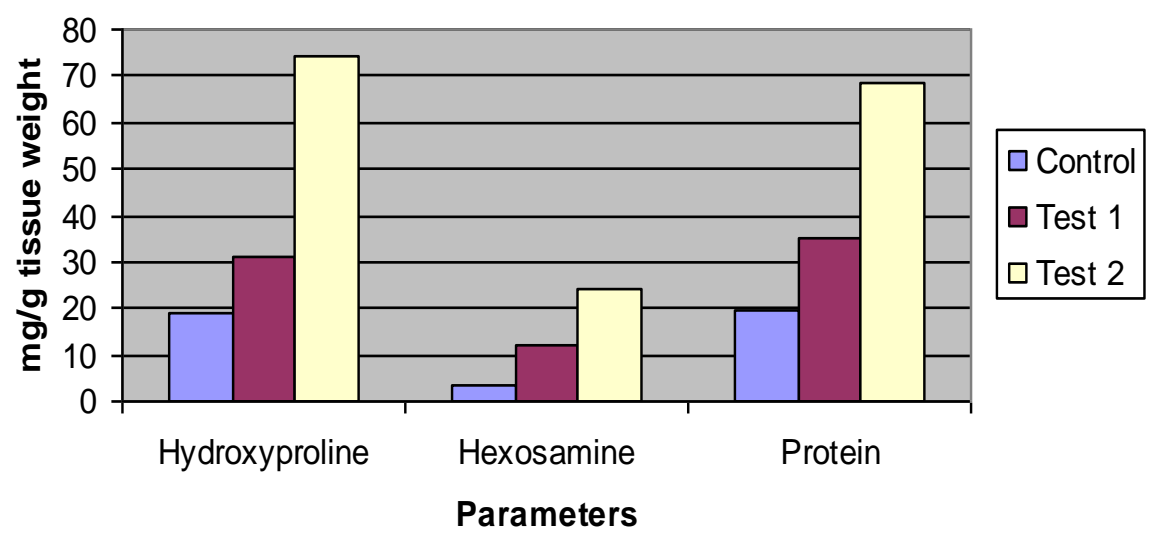

Figure 5. Biochemical parameters of excision wound model on tropical administration.

of the ethanolic extracts of the plants studied can be used both topically and orally for the healing of wounds. Single or multiple factors may play a role in any one or more individual phases, contributing to the overall outcome of the healing process (Guo and Di Pietro, 2010).

\section{REFERENCES}

Ayurvedic Pharmacopoeia of India (1998). Annony. Edn. 1, part I, vol. 1, Govt of India Ministry of Health and Family Welfare Dept of Indian System of Medicine \& Homeopathy, N. Delhi p 62.

Babu M, Gnanamani A, Radhakrishan N, Priya K (2002). Healing potential of Datura alba on burn wounds in albino rats. J. Ethnopharmacol. 83:193-199.

Dische Z, Borenfreund E (1950). A spectrophotometric method for microdetermination of heosamines. J. Biol. Chem. 84(2):517-522.

Ehrlich HP, Hunt JK (1969). The effect of cortisone and anabolic steroids on tensile strength of healing wounds. Ann. Surg. 170:203206.

Govindachari TR, Ngarajan K, Pai BR (1956). Wedelolactone from Eclipta alba. J. Sci. Ind. Res. 15:664.

Harshmohan (2002). A.T.B. of Pathophysiolog . 4th Ed. Jaypee Brothers p 152.

Lee KH (1968). Studies on mechanism of action of salicylates II.

Retardation of wound healing by aspirin. J. Pharm. Sci. 57(76):10423
Lowry OH, Rosenbrough, NJ, Farr AL, Randall BJ (1951). Protein measurement with folin phenol reagent. J. Biol. Chem. 193:265-275.

Nagelschmidt M, Struck H (1977). Hydroxyproline fractions in serum and urine of rats during wound healing. Res. Exp. Med. 170:211-215.

Malviya M, Jain S (2009). Wound healing activity of aqueous extract of Radix paeoniae root. Acta Pol. Pharm. 66(5):543-547.

Morton JJP, Malone MH (1972). Evaluation of vulnerary activity by an open wound procedure in rats. Arch. Int. Pharmacodyn. Ther. 196(1):117-126.

Nayak S, Pereira P (2006). Catharanthus roseus flower extract has wound healing activity in Sprague Dawley rats. BMC Complement. Altern. Med. 6:41-46.

Newman RE, Logman MA (1950). The determination of hydroxyproline. J. Biol. Chem. 184(1):299-306.

Purna SK, Babu M (2000). Collagen based dressings a review. Burns 26:54-62.

Rastogi PR, Mehrotra BN (1999). Compendium of Indian Medicinal Plants, vol. 3 CDRI and NISC., Lucknow, New Delhi p 32.

Rastogi RP, Mehrotra BN (1999). "Compendium of Indian Medicinal Plants" vol. 2, NISC, New Delhi, CDRI Lucknow, New Delhi p. 311.

Rastogi RP, Mehrotra BN (1999) "Compendium of Indian Medicinal Plants" vol. 4, CDRI Lucknow, NISC, New Delhi p. 311.

Guo S, Di Pietro LA (2010). Factors effecting wound healing. J. Dent. Res. 89(3):219-229.

Shanbhag T, Shenoy S, Rao MC (2005). Wound healing profile of Tinospora cordifolia. Indian Drugs 42(4):217-221.

Turner RA (1965). "Screening methods in Pharmacology". vol.1, Academic Press, London p 61. 
Wagner H, Geyer B, Kiso Y, Hikino H, Rao GS (1986). Coumestans as the main active principles of the liver drugs Eclipta alba and Wedelia calendulacea. Planta Med. 5:370-374. 